\title{
How is COVID-19 affecting the renewable energy sector and the electric power grid?
}

\author{
Hasan Huseyin Coban ${ }^{*}$ \\ *Ardahan University, Department of Electrical and Electronics Engineering, 75002, Ardahan, Turkey, (ORCID: 0000-0002-5284-0568), huseyincoban@ ardahan.edu.tr
}

(First received 4 March 2021 and in final form 18 September 2021)

(DOI: $10.31590 /$ ejosat.890451)

ATIF/REFERENCE: Coban, H. H. (2021). How is COVID-19 affecting the renewable energy sector and the electric power grid? European Journal of Science and Technology, (27), 489-494.

\begin{abstract}
It is not new to say that clean energy is better than energy from fossil fuels. What's new is that the world has a unique opportunity to accelerate clean development by putting renewable energy at the center of Covid-19 economic recovery plans. The process began with the individual quarantine of people; the closure of businesses, the decrease in the workforce and cash flow of companies, serious problems in production affected many sectors, including the energy sector, and currently, ongoing construction in power generation facilities has come to a standstill. In this study, it was investigated how the epidemic affected the renewable energy sector. Overall, energy demand fell but did not collapse completely. The most significant impact is felt in production centers and businesses where industrial demand is decreasing, but there is an increase in residential customer demand. Along with the decrease in natural gas prices, the decrease in demand caused the prices in the electricity wholesale markets to decrease. Although the fossil resources demand significantly decreased during the epidemic period, it remains uncertain for the post-epidemic period, there are signs that there may be changes in the global market structure, but the impact on renewable energy investments may be limited. On the renewable energy side, where energy investments have decreased significantly due to the epidemic, many investor companies are suffering from disruptions in the supply chain. However, the recovery of activities in China, the largest producer, will significantly reduce the negative impact in the short term.
\end{abstract}

Keywords: Covid-19 outbreak, Renewable energy sector, Sustainability transitions, Lockdown, Energy consumption.

\section{COVID-19 salgını yenilenebilir enerji sektörünü ve elektrik şebekesini nasıl etkiliyor?}

\section{$\ddot{\mathbf{O z}}$}

Günümüzde temiz enerjinin fosil yakıtlardan elde edilen enerjiden daha iyi olduğunu söylemek eski bir söylem haline geldi. Yeni olan şey, yenilenebilir enerji kaynaklarını salgının ekonomik ve sosyal iyileşme planlarının merkezine koyarak dünyanın temiz kalkınmayı hızlandırmak için eşsiz bir firsata sahip olmasıdır. Covid-19 süreci, kişilerin bireysel olarak karantinaya alınmasıyla başlamış; işletmelerin kapanması, iş gücünün azalması, üretimde yaşanan ciddi sorunlar enerji sektörü de dâhil olmak üzere birçok sektörü etkilemiş, enerji sektöründe çalışan birçok kişinin maaşlarında kesintiye gidilmiş veya işten çıkartılmış ve hâlihazırda elektrik üretim tesislerinde devam eden inşaatlar durma noktasına gelmiştir. Bu çalışmada salgının yenilenebilir enerji sektörünü ve elektrik kullanımını nasıl etkilediği araştırıldı. "Covid yılı" olarak nitelenen 2020'de küresel enerji talebi düştü ancak tamamen çökmedi. Salgınının sektördeki en büyük etkisi, endüstriyel talebin azaldığı ticarethanelerde ve üretim merkezlerinde hissedilmektedir, ancak konut müşteri talebinde artış gözlemlenmektedir. Dogalgaz fiyatlarındaki düşüş ve üretim fazlası olacağı tahminleri elektrik toptan satış fiyatlarının gerilemesine sebep oldu. Pandemi döneminde fosil kaynak talebinde ciddi oranda azalma salgın sonrası için meydana gelen olumsuz etkilerin ne kadar süreceği belirsizliğini korumakla birlikte, yenilenebilir enerji yatırımları üzerindeki etkisinin sınırlı kalabileceğine dair işaretler bulunmaktadır. Salgın nedeniyle enerji yatırımlarının önemli ölçüde azaldığı yenilenebilir enerji tarafında, yatırımcı birçok şirket tedarik zincirindeki bozulmalardan dolayı sıkıntı yaşamaktadır. Ancak, en büyük üretici konumunda olan Çin’deki üretim faaliyetlerin güç kazanmasıyla kısa vadede global enerji sektöründeki olumsuz etkiyi önemli ölçüde azaltacaktır.

Anahtar Kelimeler: Covid-19 salgını, Yenilenebilir enerji sektörü, Sürdürülebilirlik geçişleri, Karantina, Enerji tüketimi.

\footnotetext{
*Corresponding Author: huseyincoban@ardahan.edu.tr
} 


\section{Introduction}

A pandemic is known as an epidemic that spreads around the world, causing many people to get sick and die. Human history has witnessed many epidemics such as Ebola, SARS, Cholera, and MERS. Each epidemic has brought huge deaths, its global life, reaching a very large mass and spreading rapidly made these health crises difficult to control. The new type of Coronavirus disease 2019 (Covid-19) outbreak was declared as a pandemic by the World Health Organization on March 11, 2020, and has caused the deaths of 28638 people in Turkey and 2538681 people in the world by March 1, 2021 (WHO,2021). The virus, which spreads and affects all over the world rapidly, the number of cases and deaths has increased day by day. Each country is trying to reduce the impact of the epidemic with its own health system and policies implemented both economically and socially (Keith,2020).

Recently, Covid-19 and its effects on the international in various fields are being discussed all over the world. For example, during the Covid-19 outbreak, the effects on obesity (Abbas,2020), on daily life (Haleem et al.,2020), on the environment (Zambrano et al.,2020), on mitigating the health effects (Douglas et al.2020), on the nervous system (Iadecola et al.2020, Berger,2020), on business and research (Donthu and Gustafsson,2020), chemical effects of shutdowns on air quality (Kroll et al,2020), on the world economy (Fernandes,2020), on life sciences (Korbel and Stegle,2020), in the field of orthopedics (Haleem et al.,2020) are investigated. This pandemic, which affects the world, limits mobility both within and between countries while closing the countries within their borders (Pillai et al.,2020). In addition, worldwide production has slowed and trade has decreased significantly (Kejzar and Velic,2020). This decline was also reflected in the transportation sector, limiting both flights and travel by other vehicles to a great extent; in addition, quarantines or calls to stay in countries have reduced domestic transportation (Rayash and Dincer,2020).

With this general review of the literature, it is seen that there are very few studies on the effects of the Covid-19 epidemic on the energy sector. In this study, first of all, the literature related to the impact of crises on the energy sector is included. The economic effects of the Covid-19 virus on the energy sector in the global context have been tried to be determined and suggestions for the recovery of the energy sector after this epidemic have been developed.

\section{The effects of Covid-19 outbreak on the energy sector}

The energy sector is considered one of the most important economic areas for almost all countries today. Turkey's total installed power is $95000 \mathrm{MW}$ and the installed power distribution according to the source is; $31.4 \%$ hydraulic energy, $22.4 \%$ coal, $28.6 \%$ natural gas, $6.2 \%$ solar, $8.1 \%$ wind, $1.6 \%$ geothermal, and $1.7 \%$ is in the form of other sources (Gurel,2020). The pandemic is also characterized as an unprecedented crisis for the energy sector. It is known that the virus does not have a direct effect on the energy sector, as opposed to sectors such as health (Sanchez et al.,2020, Bostan et al.,2020) and tourism (Bakar and Rosbi,2020). While there has been a decrease in the energy demand of industry in countries that have implemented epidemic measures, the electricity consumption of residences has increased due to the implementation of the stay home measure. Energy prices have fallen dramatically in the market. These developments, which may seem like an opportunity for energy consumers, necessitate new paradigms for the future of the energy sector, energy-generating power plant investors and electricity producers, and new period planning in order to sustain the energy market in a stable manner.

While global energy markets are going through a difficult period due to the decrease in demand caused by Covid-19, the impact of these developments on renewable energy resources investments is also discussed in different dimensions.

\subsection{Investigation of Covid-19 process effects on the electricity demand}

As seen in Figure 1, there are three days of a demand pattern that has a general shape for Turkey (Teias,2021). It chooses three weekdays; May 13th through 15th on 2020; Wednesday through Friday; and May 13th through 15th 2019, a Monday through Wednesday (Teias,2021). The situation preCovid, pre-stay at home works; there's sort of a dip and a flattening when people move from residential buildings into commercial buildings in the middle of the day. There's a second peak when people come home, they start cooking and turn on electric stoves, TVs, lights. This curve is the general trend of electricity consumption; it can be seen in most cities. When it is compared to those same three days in 2020; it is seen that the overall demand shape is relatively consistent. It's a little bit flatter and hard to see in the Figure-1 but overall, it has a $7 \%$ reduction. There has been a big decrease in commercial buildings consuming less electricity. A lot of businesses shut down to people moving at home and consuming more electricity during the day. It is a very interesting shift in electricity consumption that's resulted in fewer power plants turning on and fewer power plants generating electricity.

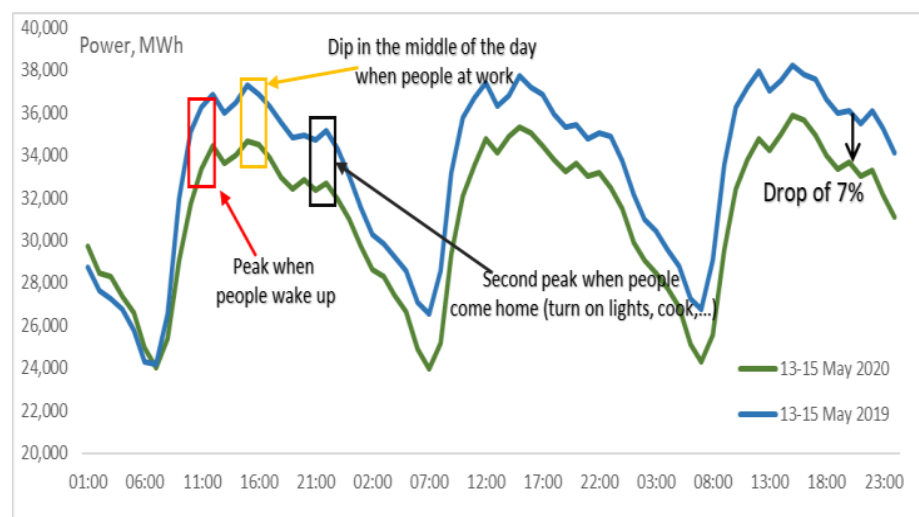

Figure 1. Electricity Demand for Turkey

Typically, rare events such as blackouts, heat waves, natural disasters have negative impacts on the electricity market. But in many countries under Covid-19, the prices are actually decreasing due to decreased demand (Tingting et al.,2021, Abadie,2021). Discussion on the possible effects of oil prices on the renewable energy sector continues within the framework of two different views.

One of the sides of the controversy argues that low oil prices will negatively affect the renewable energy sector. In other words, especially in the short term, the lack of demand in the energy market and the fall in oil prices are predicted to play a negative role in the energy transformation. Accordingly, the fact 
that electric vehicles are much less competitive with the current decreasing gasoline and fuel prices is shown as a factor that will negatively affect the trend towards renewable energy investments. It is predicted that the reduction in prices, not only in terms of vehicles, will make the use of natural gas more meaningful than wind or solar energy in electricity generation, and therefore the idea that renewable energy will be less competitive in electricity generation will reduce investments in this sector (Hoang et al.,2021). Beyond these, the negative economic consequences of the current state of the energy market strengthen the possibility that the first areas for governments to compromise are renewable energy investments and support (Bravo and Monroy,2020, Dutta et al.,2020). Apart from this, renewable energy stands out as the most important obligations of states to reduce their emissions and transform the types of energy they use in combating climate change. Considering the current state of the energy market and prices, it can be shown as another possibility that states will tend to postpone this costly transformation, which will adversely affect renewable energy sector investments, at least in the short term (IEA,2021). In addition to these, natural gas prices are mostly determined in relation to oil prices. Since natural gas is also one of the important inputs used in electricity generation in many countries, the decrease in oil prices will reduce the price of natural gas and, therefore, the cost of electricity production will decrease (Karacan et al.,2021, Hosseini,2020). In this context, it is another prediction that this situation will adversely affect renewable energy investments as electrical energy produced from renewable energy will become uncompetitive at a higher cost.

On the second view about the possible effects of oil prices on the renewable energy sector, there is the prediction (Khan et al.,2017, Miketa and Merven,2013) that the current situation in the energy market and energy prices will not have a negative impact on renewable energy investments. The long-term planning of energy investments and changes in oil prices will not affect investments in other resources, even positively affected the returns of renewable energy firms (Zhao,2020). Therefore, the current decline in demand and the drop in oil prices will not affect long-term investment planning in the renewable energy sector. As in the 1973 oil crisis, as a result of the crisis, Western states, especially France had accelerated their nuclear energy investments in order not to experience such a crisis again (Issawi,1978). Countries took an alternative way to get rid of addiction. Crises had shown states that oil could be used as a foreign policy tool. The transformation of tensions between Russia and Ukraine in 2006, 2009, and 2014 into energy crises, and on the other hand, Russia's closure of the pipeline to Ukraine for a short time caused the energy security of European countries to be negatively affected, just like the 1973 crisis, pushed European states to seek alternatives to get rid of Russian dependence (Fernández et al.2020, Graaf and Colgan,2017). This alternative is renewable energy. Therefore, it seems difficult for such a long-term transformation process to be negatively affected by short-term decreases in demand and prices, especially in the long run.

Another claim of the view that the current state of the energy market will not adversely affect renewable energy investments is based on the international economic system. The economic crisis of 2008 affected almost the whole world negatively, production slowed down and the economies of the country suffered serious losses. Renewable energy has come to the fore as a new product, a new market, and a new competition area that can revive the international economy during this economic recession (Maamary et al,2017, Brown and Ulgiati,2011). Therefore, it would not be wrong to think that a temporary decrease in demand and price will not affect the renewable energy sector negatively in the long run.

\subsection{Exogenous shocks on the present impact}

The data is on a granular scale in Ardahan city in the case of a residential building in the Camlicatak district. For a more detailed analysis in April, when the epidemic process accelerated, the same type of days (Wednesday, February 12th, and stay-at-home days Tuesday, April 14th. since i) they're weekdays, ii) people are normally at work, and iii) they have similar temperatures) was selected. Eventually, those days should have similar consumption patterns. The variation of consumption according to hours is given in Figure 2. As of April, curfews were implemented in certain periods, and the precautions are taken for the epidemic increased. Especially during the restriction period, consumption in households increased significantly. As observed in Figure 2, the biggest difference in consumption was for the hours of 08.00-22.00. The reason for this situation and the shifting of the consumption graph can be considered as the fact that people have switched to the remote working system due to the epidemic, workplaces and schools are closed, and the society is mostly at home (Kaushik and Guleria,2020). It increased from $16.9 \mathrm{kWh}$ to $21.5 \mathrm{kWh}$ which is pretty significant, that's a $29 \%$ increase in electricity consumption at the residential scale while the commercial-scale decreased due to people not going to work.

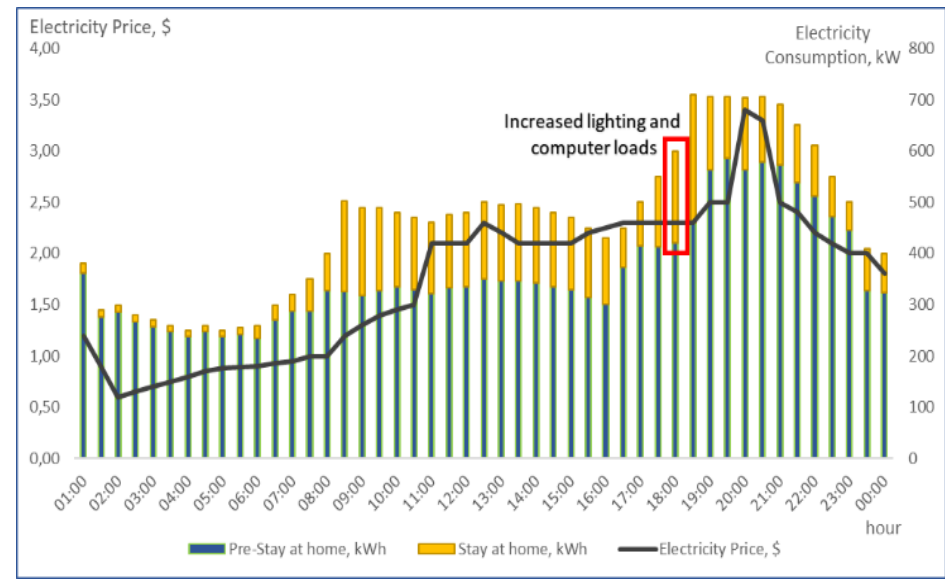

Figure 2. The residential energy consumption patterns

Beyond all this, Thomas Becker, President of the European Wind Energy Association, stated that the decline in oil prices will not reduce investment in renewable energy, the drop in oil prices was temporary, and the renewable energy transformation was not a new process, it started with the Ukraine crisis. Becker also stated that foreign dependency on energy is not sustainable, so renewable energy is a necessity in the long run to meet Europe's growing energy needs (Haase,2014).

In this context, it is possible to conclude that even if the decrease in demand due to the impact of the Covid-19 pandemic and the decrease in oil prices as a result of the Russia-Saudi Arabia oil price war may affect the renewable energy sector in the short term, it will not affect the renewable energy sector negatively in the long term. Because, first of all, it should be noted that the decrease in demand due to the effect of Covid-19 
is a temporary situation. After the pandemic countries remove both domestic and international restrictions, demand will increase and the supply-demand assessment will be made again in this period. At the same time, states have to struggle with a phenomenon, such as climate change, whose effects are different but felt absolutely everywhere in the world. The main thing in this struggle is to change the type of energy used. Renewable energy is again the main pillar of this transformation. In this context, the renewable energy sector is one of the basic elements for sustainable development. With this feature, it will remain a necessity for states to be in investment planning in the long run.

The same situation is also true for the other parts of the renewable sector. These are also stated as common concerns for the hydro and solar industry. A Norway-based research company estimates that wind and solar-related growth will decrease by $10 \%$ in 2021 (Eckhouse and Martin,2020). Considering the effects on the solar energy sector, it is seen that delays have begun to occur in global supply chains and production (Zhang et al.2021). In particular, the global effects of China, which leads the production of equipment for the solar industry, will increase over time (Radu et al.,2020). Local production of solar panels will also be affected due to raw materials supplied from China, which will mean a short-term increase in the prices of solar panels and products worldwide. China's Photovoltaic Manufacturers Association (CPIA) states that the demand forecast for China will drop to $35 \mathrm{GW}-45 \mathrm{GW}$ levels due to policy changes and delays (Osborne,2020). The quarantine process does not only slow down the sale of solar roof panels. Morgan Stanley notes that the industry is also harmed by the sudden decline in the housing industry and by consumers who stated that they could delay or cancel home renovations (Eckhouse and Martin,2020). The UK-based consulting firm Wood Mackenzie predicts a reduction of up to $50 \%$ in turbine installations (Sayigh,2020). In addition, it is estimated that 6 GW of wind capacity in the USA will be affected by the virus this year (Sayigh,2020). The extent of the impact on the businesses of the global wind turbine manufacturer Vestas is not yet clear (Weko et al.,2020). Blades and other components of Vestas wind turbines are produced in China. Many people have lost their jobs in the energy sector in the world, the clean energy sector in the US loses $18 \%$ of jobs during the epidemic (Reuters,2020), and more than a third of the wind energy industry workforce (Majumder et al.,2020). In the "Long-Term Electric Vehicle Outlook" report published by Bloomberg New Energy Finance, it was stated that the electric car market fell by $18 \%$ in 2020 due to the Covid-19 outbreak, and this decrease was $23 \%$ for internal combustion cars (Henze,2020).

\section{Discussion}

Is increased use causing the grid to be more often outside specified voltage limits?

There haven't been a lot of issues with the grid like other hazards. The lessons that can be drawn are that the grid needs multiple parts to be working in unison in order to be effective. It can not continue to rely on the supply side of large-scale power plants to solve every issue. The demand side is what consumes this electricity that's being generated. The balance between these two sides has to increase and be more seamless in order for us to have continued resilience in the grid. The increase in electricity used on the demand side has impacts on the grid. The demand is decreasing, everything is positive, but the increase in demand at the residential level has caused some voltage problems. Because e-ISSN: 2148-2683 people are consuming more in certain areas of the grid and less in other areas of the grid. There have been fluctuations in voltage due to power being consumed spatially in different locations. This is in contrast to just looking at aggregate consumption.

\section{Conclusions and Recommendations}

After the Covid-19 virus turned into a global epidemic, the process that started with individuals staying at home also significantly affected production and the workforce. Many industries came to a standstill and the electric power generation sector was affected by the epidemic in most pricing. The effects of the coronavirus epidemic have reached the cancellation and postponement of numerous international industry events in the photovoltaic, wind, hydro, battery equipment supply chain. Necessary measures should be taken quickly in order to keep the progress in solar and wind energy against the epidemic, where the epidemic has caused serious disruptions in turbine component production and turbine maintenance in the wind energy sector.

It is obvious that renewables will pass through difficulties in the short term. However, looking at the long term, it can be said that positive offers are on the horizon. The big uncertainty is how long this crisis will last and how quickly renewables can gain a competitive advantage. The general results of the study can be listed as follows:

- The grid has proven to be resilient so far through the pandemic. This is a very good thing unlike other large-scale blackouts and storms and hazards the grid during Covid has been really resilient and really reliable.

- In the event that this period, in which industrial demand decreases and housing demand increases, prolongs, low wholesale electricity prices are expected to put pressure on producers.

- In this period, where renewable energy investments have been accelerated to take advantage of government incentives, the effects of Covid-19 on the supply chain pose a great challenge for investors.

- The biggest impact of Covid -19 on the industry was experienced in the decrease in industrial demand. Despite the decline in production centers and commercial establishments, there is an increase in residential customer demand. The decrease in demand caused price drops in the electricity wholesale markets. On the renewable energy side, despite the difficulties experienced due to disruptions in the supply chain, the short-term negative impact is expected to decrease over a certain period, thanks to the recovery of activities in China.

- The benefits that can be obtained from energy transformation for Turkey during and after the Covid -19 period can be listed under the headings of economic development and environmental quality.

- If energy-dependent countries such as Turkey can direct their energy investments to renewable energy and energy efficiency with domestic equipment production support, it could go a long way towards reviving the economy with new employment opportunities that can be created.

- Countries shouldn't lose sight of their sustainability goals. Many articles and news say that there are $15 \%$ reductions in carbon emissions due to staying at home. This is great, but we shouldn't let this distract us from our main goal of integrating renewable energy into the grid. 
- Solar panels and wind turbines alone will not be able to solve climate change. On the demand side, we have to learn how to use electricity in a way that coincides with the way that the grid is operating.

\section{References}

Abadie, L. M. (2021). Energy market prices in times of COVID19: The case of electricity and natural gas in Spain. Energies, 14(6), 1632. https://doi.org/10.3390/en14061632

Abbas, A. M., Fathy, S. K., Fawzy, A. T., Salem, A. S., Shawky, M. S. (2020). The mutual effects of COVID-19 and obesity. Obesity medicine, 19, 100250. https://doi.org/10.1016/j.obmed.2020.100250

Abu-Rayash, A., Dincer, I. (2020). Analysis of mobility trends during the COVID-19 coronavirus pandemic: Exploring the impacts on global aviation and travel in selected cities. Energy research \& social science, 68, 101693. https://doi.org/10.1016/j.erss.2020.101693

Al-Maamary, H. M., Kazem, H. A., Chaichan, M. T. (2017). Renewable energy and GCC States energy challenges in the 21st century: A review. International Journal of Computation and Applied Sciences IJOCAAS, 2(1), 11-18.

Bakar, N. A., Rosbi, S. (2020). Effect of Coronavirus disease (COVID-19) to tourism industry. International Journal of Advanced Engineering Research and Science, 7(4), 189-193. https://dx.doi.org/10.22161/ijaers.74.23

Berger, J. R. (2020). COVID-19 and the nervous system. Journal of neurovirology, 26, 143-148. https://doi.org/10.1007/s13365-020-00840-5

Bostan, S., Erdem, R., Öztürk, Y. E., Kılıç, T., Yılmaz, A. (2020). The Effect of COVID-19 Pandemic on the Turkish Society. Electronic Journal of General Medicine, 17(6). https://doi.org/10.29333/ejgm/7944

Brown, M. T., Ulgiati, S. (2011). Understanding the global economic crisis: A biophysical perspective. Ecological Modelling, 223(1), 4-13. https://doi.org/10.1016/j.ecolmodel.2011.05.019

B. Majumder, S. Hardin, C. Moser, (2020), The Impact of the Coronavirus on the Renewable Energy Industry https://www.americanprogress.org/issues/green/news/2020/0 4/15/483219/impact-coronavirus-renewable-energyindustry/

Cansado-Bravo, P., Rodríguez-Monroy, C. (2020). The Effects of Structural Breaks on Energy Resources in the Long Run. Evidence from the Last Two Oil Price Crashes before COVID-19. Designs, 4(4), https://doi.org/10.3390/designs4040049

Donthu, N., Gustafsson, A. (2020). Effects of COVID-19 on business and research. Journal of business research, 117, 284. https://doi.org/10.1016/j.jbusres.2020.06.008

Douglas, M., Katikireddi, S. V., Taulbut, M., McKee, M., McCartney, G. (2020). Mitigating the wider health effects of covid-19 pandemic response. Bmj, 369.

https://doi.org/10.1136/bmj.m1557

Dutta, A., Jana, R. K., Das, D. (2020). Do green investments react to oil price shocks? Implications for sustainable development. Journal of Cleaner Production, 266, 121956. https://doi.org/10.1016/j.jclepro.2020.121956

Eckhouse, B., Martin, C. (2020). Coronavirus Crushing Global Forecasts for Wind and Solar Power. Bloomberg Green.
Fernandes, N. (2020). Economic effects of coronavirus outbreak (COVID-19) on the world economy. Available at SSRN 3557504. https://dx.doi.org/10.2139/ssrn.3557504

Gurel, B. (2020). Türkiye'deki Güncel Biyokütle Potansiyelinin Belirlenmesi ve Yakılmasıyla Enerji Üretimi İyi Bir Alternatif Olan Biyokütle Atıklar İçin Sektörel Açıdan ve Toplam Yanma Enerji Değerlerinin Hesaplanmas1. Mühendislik Bilimleri ve Tasarım Dergisi, 8(2), 407-416. https://doi.org/10.21923/jesd.671767

Haleem, A., Javaid, M., Vaishya, R. (2020). Effects of COVID 19 pandemic in daily life. Current medicine research and practice. https://doi.org/10.1016/j.cmrp.2020.03.011

Haleem, A., Javaid, M., Vaishya, R., Vaish, A. (2020). Effects of COVID-19 pandemic in the field of orthopaedics. Journal of clinical orthopaedics and trauma,11(3), 498. https://doi.org/10.1016/j.jcot.2020.03.015

Hoang, A. T., Nižetić, S., Olcer, A. I., Ong, H. C., Chen, W. H., Chong, C. T., ... Nguyen, X. P. (2021). Impacts of COVID19 pandemic on the global energy system and the shift progress to renewable energy: Opportunities, challenges, and policy implications. Energy Policy, 154, 112322. https://doi.org/10.1016/j.enpol.2021.112322

Hosseini, S. E. (2020). An outlook on the global development of renewable and sustainable energy at the time of COVID19. Energy Research \& Social Science,68, 101633. https://doi.org/10.1016/j.erss.2020.101633

Iadecola, C., Anrather, J., Kamel, H. (2020). Effects of COVID19 on the nervous system. Cell. https://doi.org/10.1016/j.cell.2020.08.028

IEA, Renewable Energy Market Update Outlook for 2020 and 2021, International Energy Agency, p:16.

Issawi, C. (1978). The 1973 oil crisis and after. Journal of Post Keynesian Economics, 1(2), 3-26. https://doi.org/10.1080/01603477.1978.11489099

Karacan, R., Mukhtarov, S., Barış, İ., İşleyen, A., Yardımcı, M. E. (2021). The Impact of Oil Price on Transition toward Renewable Energy Consumption? Evidence from Russia. Energies, 14(10), 2947.

https://doi.org/10.3390/en14102947

Kaushik, M., Guleria, N. (2020). The impact of pandemic COVID-19 in workplace. European Journal of Business and Management, 12(15), 1-10. https://doi.org/10.7176/ejbm/12$\underline{15-02}$

Keith, K. (2020). COVID-19 Package\# 3: The coverage provisions. Health Affairs blog. https://www. healthaffairs. org/do/10.1377/hblog20200320, 739699.

Kejzar, K. Z., Velic, A. (2020). Covid-19, trade collapse and GVC linkages: European experience. Covid Economics, 61, 222-244.

Khan, M. I., Yasmeen, T., Shakoor, A., Khan, N. B., Muhammad, R. (2017). 2014 oil plunge: Causes and impacts on renewable energy. Renewable and Sustainable Energy Reviews, 68,

609-622. https://doi.org/10.1016/j.rser.2016.10.026

Korbel, J. O., Stegle, O. (2020). Effects of the COVID-19 pandemic on life scientists. https://doi.org/10.1186/s13059020-02031-1

Kroll, J. H., Heald, C. L., Cappa, C. D., Farmer, D. K., Fry, J. L., Murphy, J. G., Steiner, A. L. (2020). The complex chemical effects of COVID-19 shutdowns on air quality. Nature Chemistry, 12(9), 777-779. https://doi.org/10.1038/s41557$\underline{020-0535-\mathrm{Z}}$ 
Miketa, A., Merven, B. (2013). West African power pool: Planning and prospects for renewable energy.

N. Haase (2014), DW https://www.dw.com/en/what-future-foreus-energy-supply/a-17542697

Osborne M., "BloombergNEF cuts global solar demand forecast on coronavirus concerns", https://www.pvtech.org/news/bloombergnef-cuts-global-solar-demandforecast-on-coronavirus-concerns

Pereira-Sanchez, V., Adiukwu, F., El Hayek, S., Bytyçi, D. G., Gonzalez-Diaz, J. M., Kundadak, G. K., ... da Costa, M. P. (2020). COVID-19 effect on mental health: patients and workforce. The Lancet Psychiatry, 7(6), e29-e30. https://doi.org/10.1016/S2215-0366(20)30153-X

Pillai, S., Siddika, N., Apu, E. H., Kabir, R. (2020). COVID-19: Situation of European countries so far. Archives of medical research, 51(7),

723-725. https://doi.org/10.1016/j.arcmed.2020.05.015

Radu, A., Panaite, C. E., Popescu, A. (2020, December). Impact of COVID-19 pandemic on renewable sources implementation: case of PV systems in Romania. In IOP Conference Series: Materials Science and Engineering (Vol. 997, No. 1, p. 012154). IOP Publishing. https://doi.org/10.1088/1757-899X/997/1/012154

Reuters, (2020) Oil Report, June 15, 2020, US clean energy sector loses $18 \%$ of jobs during pandemic,

https://www.reuters.com/article/usa-clean-energy-jobs/us-cleanenergy-sector-loses-18-of-jobs-during-pandemic-reportidINL1N2DS18M?edition-redirect=in

Rodríguez-Fernández, L., Carvajal, A. B. F., Ruiz-Gómez, L. M. (2020). Evolution of European Union's energy security in gas supply during Russia-Ukraine gas crises (20062009). Energy Strategy Reviews, 30, 100518. https://doi.org/10.1016/j.esr.2020.100518

Sayigh, A. (2020). Solar and wind energy will supply more than $50 \%$ of world electricity by 2030 . In Green Buildings and Renewable Energy (pp. 385-399). Springer, Cham.

TEİAŞ YTBS, https://ytbsbilgi.teias.gov.tr/ytbsbilgi/frm istatistikler.jsf

Tingting Xu, A., Weijun Gao, B., Yanxue Li, C., Fanyue Qian, D. (2021). Impact of the COVID-19 pandemic on the reduction of electricity demand and the integration of renewable energy into the power grid. Journal of Renewable and Sustainable Energy, 13(2), 026304. https://doi.org/10.1063/5.0045825

Van de Graaf, T., Colgan, J. D. (2017). Russian gas games or well-oiled conflict? Energy security and the 2014 Ukraine crisis. Energy Research \& Social Science, 24, 59-64. https://doi.org/10.1016/j.erss.2016.12.018

Weko, S., Eicke, L., Quitzow, R., Bersalli, G., Lira, F., Marian, A., ... Xue, B. (2020). Covid-19 and Carbon Lock-In: Impacts on the Energy transition.

World Health Organization (WHO), https://covid19.who.int/region/euro/country/tr

Zambrano-Monserrate, M. A., Ruano, M. A., Sanchez-Alcalde, L. (2020). Indirect effects of COVID-19 on the environment. Science of the Total Environment, 728, 138813. https://doi.org/10.1016/j.scitotenv.2020.138813

Zhang, H., Yan, J., Yu, Q., Obersteiner, M., Li, W., Chen, J., ... Shibasaki, R. (2021). 1.6 million transactions replicate distributed PV market slowdown by COVID-19 lockdown. Applied Energy, 283, 116341. https://doi.org/10.1016/j.apenergy.2020.116341
Zhao, X. (2020). Do the stock returns of clean energy corporations respond to oil price shocks and policy uncertainty? Journal of Economic Structures, 9(1), 1-16. https://doi.org/10.1186/s40008-020-00229-x

Veronika Henze, (2020). Electric Vehicle Sales to Fall $18 \%$ in 2020 but Long-term Prospects Remain Undimmed. BloombergNEF. 